\title{
Téma vykořenění a ztrát v současné próze. Nad románem Jakuby Katalpy Němci
}

\author{
Petr Kučera (Plzeň)
}

\begin{abstract}
Abstrakt
Studie analyzuje román Němci (2012) české prozaičky Jakuby Katalpy jako pokus o nový pohled na problematiku života německé menšiny $v$ Československu od meziválečného období až po divoké vyhánění a následné organizované vysídlení německy mluvících obyvatel po skončení druhé světové války. Román představuje skrytou polemiku s ideologicky a morálně akcentovanými prístupy k tématu - v české próze do roku 1989 výrazně protiněmecky orientované, od devadesátých let naopak často adorující sudetské Němce jako kladné hrdiny. Na rozdil od svých dříěejších experimentálních próz psaných složitým jazykem vytvořila autorka v románu Němci zajímavou kombinaci kultivovaného současného jazyka, věcného stylu a stále se větvící narativní struktury, ve které dominuje každodenní život intenzivně vnímaný všemi smysly.
\end{abstract}

\section{Klíčová slova}

současná česká próza; německá menšina v Československu; narativní struktura; jazyk a styl; román Němci; Jakuba Katalpa

\section{Abstract \\ The Theme of Uprooting and Loss in Contemporary Prose. Over the Novel The Germans by Jakuba Katalpa}

The study analyzes the novel Němci (The Germans, 2012) of the Czech prose writer Jakuba Katalpa as an attempt at a new perspective on the issue of the life of the German minority in Czechoslovakia from the interwar period to the wild expulsion and subsequent organized displacement of German-speaking inhabitants after the end of the Second World War. The novel represents a concealed polemic with ideologically and morally accented approaches to the subject - in Czech prose until 1989 significantly anti-German oriented, since the nineties on the contrary, often adoring Sudeten Germans as positive heroes. Unlike its earlier experimental narrations written in a complex language, the author made in the novel Němci (The Germans) an interesting combination of cultivated contemporary language, material style and ever-branching narrative structure dominating everyday life intensely perceived by all senses.

\section{Key words}

contemporary Czech prose; German minority in Czechoslovakia; narrative structure; language and style; the novel Němci (The Germans); Jakuba Katalpa 
Téma vykořenění a ztrát je v souvislosti s německou menšinou v českých zemích zatíženo v moderní próze několika stereotypy. Do devadesátých let 20. století je postava českého, moravského nebo slezského Němce (označovaného dnes na celém území republiky nepřesným, ale vžitým názvem „sudetský Němec“) více či méně záporná, navíc pravidelně zostřuje konflikt. Po demokratickém převratu v roce 1989 došlo v české próze k morálnímu přehodnocování postav sudetských Němců - z bývalých stoupenců nacismu se stávají kladné postavy bezbranných obětí českého násilí. Zatímco spisovatelé nenabídli strukturovanější pohled, v pracích historiků, sociologů i publicistů se veřejnost hlubší reflexe nedávné minulosti dočkala. ${ }^{1}$

Oficiální, propagandou zprostředkovávaný stereotyp o spravedlivém odsunu nacisticky smýšlejících Němců z poválečného Československa tak od počátku devadesátých let 20. století narušují stále častěji nové informace o odsunu nejen aktivních nacistů, ale i lidí zcela apolitických, části německých antifašistů či dokonce obětí hitlerovského režimu - německy mluvících Židů, kteří se na konci války vrátili z koncentračních táborů. V Československu naopak zůstali aktivní nacisté, kteří byli jako odborníci nenahraditelní zejména v textilním průmyslu nebo měli speciální znalosti a dovednosti využitelné např̀ v tajných službách nového režimu. ${ }^{2}$

Ani odborníci-historikové se však neshodnou v pohledu na soužití Čechů a Němců. Česká veřejnost je - vedle idylických obrázků dávné pospolitosti - konfrontována s tvrzeními, že obě etnika žila po dlouhou dobu osmi století v českých zemích nikoli spolu, ale spíše vedle sebe, v příznivých obdobích docházelo často ke konfliktům a ochotu si vzájemně pomáhat prokazovali Češi a Němci převážně jen v časech nouze.

Pro generace, které dobu česko-německého soužití nepamatují, představují sudetští Němci etnikum poněkud záhadné - v současné české společnosti se o něm mluví převážně jen v politických souvislostech poválečného vysídlení a ještě zcela nedávno vznášených požadavků Sudetoněmeckého krajanského sdružení na materiální odškodnění. Očekávání, že román Němci přispěje ke změně, však autorka zjevně nemínila naplňovat. Přesto je tato próza v několika ohledech pozoruhodná.

Česká prozaička a výtvarnice Jakuba Katalpa (vlastním jménem Tereza Jandová, narozená v Plzni roku 1979) zaujala již svou novelou z roku 2006 - její experimentální próza s erotickými motivy Je hlína $k$ snědku? se zařadila mezi díla nominovaná v kategorii objev roku na cenu Magnesia Litera. Román Hořké moře byl roku 2009 nominován na Cenu Jiřího Ortena pro mladé autory; porota ocenila „fabulační odvahu a energický, osobitý styl vyprávění.“

1 Nová fakta a nové pohledy přinášejí zejména následující monografie a soubory studií: STANĚK, Tomáš: Odsun Němců z Československa 1945-1947. Praha: Academia, 1991; STANĚK, Tomáš: Poválečné „excesy“ v českých zemich v roce 1945 a jejich vyšetřováni. Praha: Ústav pro soudobé dějiny AV ČR, 2005; STANĚK, Tomáš - von ARBURG, Adrian (eds.): Vysídlení Němců a proměny českého pohraniči 1945-1951 I. Středokluky: SUSA, 2010.

2 Srov. odlišné pohledy na sudetské Němce ve výše uvedených pracích T. Staňka a v následujících publikacích: DVOŘÁK, Tomáš - KOVǍ̌ÍK, David - von ARBURG, Adrian: Německy mluvici obyvatelstvo v Československu po roce 1945. Brno: Matice moravská, 2010; HAHNOVÁ, Eva: Sudetoněmecké vzpominání a zapomináni. Praha: Votobia, 2002; KURAL, Václav: Misto společenstvi - konflikt! Praha: Ústav mezinárodních vztahů, 1994. 
Za román Němci z roku 2012 získala autorka v roce 2013 Cenu Josefa Škvoreckého. Román byl přeložen do pěti jazyků (včetně němčiny). Autorka vstoupila románem Němci nejen do povědomí odborné kritiky a překladatelů, ale i širší čtenářské veřejnosti, o čemž svědčí mj. druhé vydání v brněnském nakladatelství Host v roce 2014. Nejnovější prózou Jakuby Katalpy je pak román Doupě, který vyšel v roce 2017.

V románech Němci a Doupě opustila autorka svůj dřívější provokativně experimentální tón a vyšla částečně vstříc čtenáři. Katalpa však stále zůstává suverénní tvůrkyní svébytných fikčních světư ${ }^{3}$, jejichž funkce rozhodně není v prvé řadě dokumentární, což je nutné mít zejména u románu Němci stále na paměti. Autorka, která vyrůstala a žije v příhraničním prostoru označovaném jako Sudety ${ }^{4}$, uchopila citlivé téma německé menšiny na území bývalého Československa způsobem, který je do značné míry nový. ${ }^{5}$

V současné české próze se tématem vykořenění v souvislosti s německou menšinou zabývají vedle Katalpy další české autorky. S úspěchem u odborné kritiky i u čtenářů se setkaly romány Radky Denemarkové Penize od Hitlera (2006) a Vyhnáni Gerty Schnirch (2009) Kateřiny Tučkové. ${ }^{6}$ Není bez zajímavosti, že jde ve všech třech případech o ženy, které otevírají bolavé rány česko-německých vztahů, třebaže nedisponují ani osobními vzpomínkami, ani odborným zázemím historiografie a sociologie.

Spisovatelky věří v bezmeznou sílu své imaginace a ženské empatie, a tak neváhají nabídnout pohled Němců na danou dobu. Někdy fabulují tak nespoutaně, že se čtenář zdráhá fikci uvěřit (Radka Denemarková), jindy chystají čtenáři rébusy a pasti v podobě složitě zřetězených, jen zlehka naskicovaných a posléze opuštěných postav či dějových odboček (Kateřina Tučková a Jakuba Katalpa). Odvaha, s níž se zmocňují tabuizovaného tématu, je však pro českou společnost natolik důležitá, že vyváží i některé problémy při konstruování literární formy.

Jakuba Katalpa přistupuje k vytvoření obrazu Němců v českých zemích ze zcela jiné strany, než bylo v české próze dosud běžné - aspekty politické, etické či sociálně psychologické ji zajímají pouze jako kontext, z něhož vybírá útržkovité dobové citáty známých aktérů, jejichž absurdita se vyjevuje v kontrastu s historickou realitou. Proti odleskům tzv. velké historie staví autorka malou historii každodennosti obyčejných lidí, především žen,

3 K problematice fikčních světů srov. zejména následující studie: COHNOVÁ, Dorrit: Signály fikčnosti: Naratologický pohled. Přel. M. Orálek. In: Aluze 10, 2008, č. 1, s. 40-54; DOLEŽEL, Lubomír: Inovace jako transformace fikčniho světa. In: Týž: Studie z české literatury a poetiky. Ed. a překl. B. Fořt. Praha: Torst, 2008, s. 289-300; DOLEŽEL, Lubomír: Fikčni a historický narativ. In: Týž: Studie z české literatury a poetiky. Ed. a překl. B. Fořt. Praha: Torst, 2008, s. 301-336; FOŘT, Bohumil: Úvod do sémantiky fikčních světůi. Brno: Host, 2005.

4 Výraz "Sudety“ vznikl z geomorfologického označení severních hraničních hor a podhůř́i zemí Koruny české, stále častěji se však používá k označení okrajových oblastí (nejen severních), které byly osídleny převážně německy mluvícím obyvatelstvem.

5 Srov. rozhovor Ivany Myškové s Jakubou Katalpou Román Němci může být pro čtenáře velkým překvapením. In: Český rozhlas - Vltava ze dne 31. 1. 2013, dostupné z: http: vltava.rozhlas.cz/roman-nemci-muze-byt-pro-ctenare-velkym-prekvapenim.

6 Román Penize od Hitlera obdržel v roce 2007 cenu Magnesia Litera v kategorii próza, v Německu získal usedomskou literární cenu. V roce 2010 uvedlo Švandovo divadlo v Praze adaptaci románu, v roce 2014 vznikla i adaptace filmová. Román Vyhnáni Gerty Schnirch získal v roce 2010 cenu Magnesia Litera (Cena čtenářů Knižního klubu), divadelní adaptaci uvedlo v roce 2014 HaDivadlo v Brně. 
které překvapují přímočarostí, tvrdostí, odolností a zvláštní umanutostí. Pavel Janoušek spatřuje v románovém stylu Jakuby Katalpy rysy mužské věcnosti: „Katalpa se v románu Němci projevuje jako profesionálně zdatná spisovatelka, vyprávějici stylem až mužsky věcným a úsečným, mnohdy i ironickým a drsným, a to prostřednictvím krátkých a zpravidla také jemně vypointovaných kapitol. "7

Dá-li se o jakési „mužské“ věcnosti a úsečnosti v románu Němci uvažovat, pak v rovině jazykově stylistické, nikoli ve výběru detailů. Čtenáře hledající jednoznačné role a pozice autorka dokonale mate zcizujícími detaily připomínajícími tzv. severočeskou školu prózy šedesátých až osmdesátých let 20. století. Pozoruhodný je autorčin umělecký pseudonym Jakuba Katalpa - neobvykle působí přechýlení chlapeckého jména Jakub; př́ijmení Katalpa pak označuje strom pocházející ze Severní Ameriky, který je v Evropě pěstován jako okrasný, má nepravidelnou korunu a všechny jeho části jsou mírně jedovaté. ${ }^{8}$ Takové jsou i vypravěčské triky a rafinovaně konstruované pasti, do nichž je čtenář lákán.

V úvodní pasáži románu vypráví mladá žena, která po smrti svého nevyzpytatelného a depresivního otce hledá v Německu jeho biologickou matku, od níž přicházely ze západního Německa dlouhá léta balíky se sladkostmi. Klára Rismannová, pravá babička bezejmenné personální vypravěčky, se stává narativním hlasem téměř celého románu pouze v závěru je nahrazena původní vypravěčkou.

Otec mladé vypravěčky se nemohl vyrovnat s představou, že ho jeho vlastní matka nechala doma, a utápěl se při rozbalování balíků v projevech nenávisti:

„Jak mi to mohla udělat?“ ‘̌ekl otec, když jsem se ho před lety zeptala na babičku Rissmannovou.

Osobni historie rozplizlá do neurčita; na otázku odpověděl otázkou. Nevím, jestli by ho potěšilo, kdyby zjistil, že jeho matka ještě žije; možná by pocítil zadostiučiněni, že babička kviili své selhávajici paměti zapomnèla nejen na něj, ale také na své ostatni dèti.

Dotkla se mě téměr šedesát let stará bolest, a tentokrát to neni pouze bolest mého otce, tolikrát deklamovaná a prožívaná bezmála slavnostně, ale hlodá ve mně ještě něco jiného, nejistota a zármutek, zjištěni, že mezi pravdou a lži je tak tenká hranice, že ji lze setřít jediným pohybem ruky, kmitnutím očních víček. ${ }^{9}$

Mladá vypravěčka se po otcově smrti pustí neohroženě a důsledně do téměř detektivního pátrání po babičce, která opustila svého syna a nikdy ho pak již nevyhledala (motivace tohoto činu zůstává po celou dobu opředena tajemstvím). Svou tetou je přivedena do ústavu k ženě vysokého věku, která trpí demencí, a tak jí vnučka nemůže klást nepříjemné otázky. Čtenářské očekávání ponoru do nejtěžšího období česko-německých vztahů je zklamáváno př́iběhem ženy, která dramatické události nereflektuje, ale zakouší jejich důsledky doslova na svém těle. Autorka fabuluje životní příběh Kláry Rismannové jako sled životních ztrát. Svéráznou „geografii ztrát“ rozvíjí pomocí obrazů, v nichž hraje mimořádně důležitou roli smyslové vnímání.

7 JANOUŠEK, Pavel: 969 slov o próze Jakuba Katalpa: Němci. Host, Brno 2012. In: Tvar 21, 2012, s. 3.

8 K problematice osobních jmen srov. např.: KNAPPOVÁ, Miloslava: Jak se bude vaše dítě jmenovat? 5 . vyd. Praha: Academia, 2010; k českým př́ijmením viz MOLDANOVÁ, Dobrava: Naše př̌́jmení. 4. vyd. Praha: Agentura Pankrác, 2015.

9 KATALPA, Jakuba: Němci. Brno: Host, 2012, s. 50. 
Uhranutí tělesnými projevy je specifikem stylu Jakuby Katalpy. Detaily fyziologických procesů jsou využity funkčně, čtenář se ocitá všemi smysly uprostřed dávných dějů. Namísto ideologicky zatížených stereotypů se tak autorce podařilo něco, co je v současné literatuře vzácné - navrací zkušenost zpátky do jazyka.

Věcnost a stylová neutrálnost jazyka této prózy dává vyniknout hodnotové nejednoznačnosti chování postav v kritických životních situacích, nebot vypravěčka se vyhýbá morálním, ale i estetickým soudům. Zvláštní zálibu má ve všech lidských tekutinách, o nichž se zmiňuje v decentních náznacích, bez povrchového naturalismu. Slzy, pot, krev, sperma, moč i lidské lejno na cestě získávají symbolický význam autentického bytí v odlehlé pohraniční oblasti. Sudetští Němci se v románu Jakuby Katalpy stávají lidmi z masa a kostí, přestávají být záhadnými kreaturami nebo chudáky vzbuzujícími soucit.

Neobvyklé je emancipované chování babičky Rissmanové, která v odlehlé vesnici, kam byla poslána jako učitelka, sama naváže sexuální vztah s rasem Weissmannem. Podobně jako její učitelský kolega Fuchs přistoupí na nabídku zástupce školního rady, aby v dopisech zasílaných na školní inspektorát donášela na ostatní učitele. Morální apatie čiší z lehkosti, s níž se vypravěčka vyrovnává s problémem udavačství:

„Překvapilo jí to, domnívala se, že bude psát př́mo na ministerstvo školství. Systém byl zrejmě rafinovanější, než si myslela.

Malke ji dopodrobna seznámil s tím, co se od ni čeká. Během jednoho měsice měla objet nejméně dvě školy $v$ kraji a poznamenat si, jak je na nich vedena výuka, dalši měsíc měla to samé udèlat s jinými dvěma školami a celé to mèla opakovat tak dlouho, dokud nedorazi ke školám, kde začínala.

Kolečko hrůzy.

O rajón se dělila s Fuchsem. Nemohla ovšem vyloučit, že ona sama je jeho rajónem; on byl rozhodně ve středu jejiho zájmu.

„Kdyby se vám něco nezdálo na Fuchsovi, “ ̌rekl Malke, „bez obav se o tom zmiňte v dopisech.“

Zeptala se, po čem presně by měla pátrat.

„Po jakékoliv známce neloajality, “ odvětil Malke a to ji umlčelo. ${ }^{10}$

Namísto objíždění vesnických škol si Klára vymýšlela pozitivní zprávy a ptala se sama sebe, zda si Fuchs také vymýšlí, když o ní podává hlášení. Kvůli používání zakázané češtiny dětmi ze smíšených, ale i německých rodin podnikla několik návštěv - někteří rodiče slíbili, že dohlédnou, aby děti česky nemluvily, jiní se této aktivitě mladé učitelky přímo vysmáli. V Kláře se opakovaně sváří smysl pro povinnost se zvláštní lhostejností k morálním a společenským problémům, o nichž ovšem vždy alespoň něco tuší. Týká se to nejen dopisů hodnotících loajalitu kolegů k nacistickému režimu, ale i transportů židovských spoluobčanů do koncentračních táborů, které oficiální propaganda líčila jako pouhé tábory pracovní. Klára je při společné cestě osobním vlakem s knihovníkem zámecké knihovny Melmanem konfrontována s nákladním vlakem odjíždějícím z nádraží opačným směrem:

10 Tamtéž, s. 215-216. 
„Ano, dokázala si predstavit, že lidé převáženi dobytčími vagóny se zamř́žovanými okny jsou ti, kdo spáchali nějaký zločin.

„Přremýšlel jsem nad tím, přestože jsem to věděl, “ ̌rekl Melman.

„Židé?"

Nikdo jiný ji nenapadl.

Melman prikívl.

„Zřejmě byli na cestě do některého z pracovnich táborü, “ uvažovala hlasitě.

„Ne. “

Udiveně na něj pohlédla.

„Myslim, že jeli umř́t. "11

[...]

To, že by Židé mohli být usmrcováni, jí připadalo neuvěritelné. Neuměla si představit, jakým zpưsobem by něco takového mohlo probihat; když přmemýlela nad realitou tèla, jeho hmotností, velikosti a silou - a navíc vzala v potaz pravděpodobný odpor jeho majitele -, nezdálo se ji možné, že by kdokoliv a jakkoliv mohl vyhubit celý vlak. ${ }^{12}$

$[\ldots]$

Na návsi klopýtla. Oprela se o kmen lípy, zhluboka se nadechla, pak si zapálila cigaretu. Byla podráždèná; $i$ kdyby byli Židé tak nevybiravě odstrañováni, copak se to týkalo ji osobně?

Znovu se vydala na cestu. ${ }^{13}$

Umírání školního inspektora Malkeho na rakovinu naopak Kláru zasáhlo, protože s touto smrtí měla osobní zkušenost:

Letmo prozkoumala léky na nočnim stolku, zaregistrovala lahvičku s morfiem, injekčni stř̌kačku a tubu s prášky na spani. Ucítila, jak se ji stahuje hrdlo. Malke ji nijak zvlášt’ neprirostl $k$ srdci, a presto se nedokázala ovládnout, jeho umíráni bylo tak hmatatelné, jako by se týkalo ji samé. ${ }^{14}$

Po přeletu letadel západních spojenců nad vesnicí je Klára udivena Weissmannovým vysvětlením, že Německo válku nevyhraje. Neměla přístup k informacím ze západních médií, politické a vojenské situaci nerozuměla a nezajímala se o ni. Odmítla i nabídku svého otce, který si prohru Německa připustil s předstihem, a proto zajistil pro svou rodinu únikovou cestu do Švýcarska - otci oznámila, že chce ve vesnici Rzy zůstat:

Neuměla si predstavit, že by odešla. Už př́liš dlouho byla součástí krajiny, hor, strusky z peci vyvážené do lesü, bilého vyklenuti nebe, úzkých pěšin protkávajicích les.

Zničila si tu plice, v Hinterbergenu nikdy tolik nekouřila. Měla by ted'opustit všechny nedopalky, které

11 Tamtéž, s. 260.

12 Tamtéž, s. 261.

13 Tamtéž, s. 262.

14 Tamtéž, s. 282. 
špičkou boty zahrnula jehličim, zapichla do květináču na školni chodbě nebo odhodila do potoka?

Nikdy.

Zůstane věrná tabáku.

Meine Ehre heisst Treue. ${ }^{15}$

Navzdory ironii, kterou provází každý náznak sentimentu, je patrné Klářino propojení s rodnou zemí. Ironicky vyznívá také většina aluzí na hesla nacistické propagandy, která se ocitá stále více mimo realitu konce války. Klára se naopak - i díky Fuchsovým informacím ze zahraničního rozhlasu - snaží vyrovnat s faktem německé prohry:

\section{Šestnáctého dubna zaslechla Klára vzdálené dunění poprvé.}

Vyšla na náves a vmísila se do hloučku lidi napjatě hledicich $k$ obzoru.

„Rusové, “ rekl nèkdo a Klára pochopila, že nastal konec časů, na které byla zvyklá.

Obrátila se a vrátila se do školy. V chodbě se ji sevřel žaludek, takže se musela opřít o stěnu a na okamžik zavř́t oči .

O dva dny později se ve škole zastavil inspektor Paetzke s př̌kazem ukončit výuku. ${ }^{16}$

$$
[\ldots]
$$

Jeji život se naplnil čekáním, záchvaty vzrušeni a neklidu se stř́daly s pocitem otupěni. Fuchs, jenž ji zásoboval čerstvými zprávami z rozhlasu, vypadal stále sklesleji.

„Prohráli jsme, “ ̌rekl, když se dozvěděl o dalším bombardováni Drážd’an.

Klára, uviznuvši ve vesnici sevřené z obou stran horami, mèla pocit, že se ocitla na konci světa. Strach se podobal vlně nesouci každého jiným směrem a nebylo možné jej sdilet, odděloval ji od Fuchse i od Weissmanna. ${ }^{17}$

Útěk Klářina sexuálního partnera Weissmanna z vesnice, kde chtěl zanechat ji i své syny, způsobil Kláře tak silnou nevolnost, že se pokusila o vraždu - bodla Weissmanna nožem do zad a ve stavu zvláštní rozjařenosti běžela Fuchsovi sdělit, že Weissmanna zabila. Později se však ukázalo, že nůž se zastavil o lopatku a zranění nebylo vážné.

Po válce přicházejí z vnitrozemí do pohraničí čeští přistěhovalci a obsazují domy po Němcích. Klára se s učitelem Fuchsem musí přestěhovat do jedné malé místnosti bývalého výměnku. Klářina zvláštnost a nezařaditelnost se projeví i ve skutečnosti, že zmizí z evidence, a tak ji po válce na jedné straně nelze poskytovat potravinové a šatní lístky, na druhé straně ji ale také nelze odsunout. Učitel Fuchs se cítí nesmírně silně spjat se svou rodnou zemí a se svým povoláním. Z vesnice nedokáže odejít a raději spáchá sebevraždu skokem do studny.

Posly zkázy se stávají v románu také věci, jejichž bytí je tajemně propojeno s bytím lidí. Na zarostlém venkovském hřbitově je jím pískovcový anděl, který ztratil křídlo. Klára prochází se zapálenou cigaretou hřbitovem a vnímá beznadějnou opuštěnost místa:

\footnotetext{
15 Tamtéž, s. 308.

16 Tamtéž, s. 315.

17 Tamtéž, s. 317.
} 
Mrtvi byli odsunuti do pozadi, nebyl tu nikdo, kdo by opatroval mista jejich posledního odpočinku. Pozůstali, kteři o hroby pečovali, byli vysídleni, uprchli nebo se rozptýlili po okolnich vesnicich.

Také hrob Fuchsovy matky byl zanedbaný. V mramoru zešedlém špínou spatřila Klára odraz Fuchsova zoufalství. Dotkla se studeného náhrobku; bylo to, jako by nahlédla do Fuchsovy unavené duše. ${ }^{18}$

Autorka postupně buduje obraz ženství, který v české próze není obvyklý - nejen bez psychologizování, ale i bez brýlí apriorního (a tedy ideologizujícího) genderismu. Radomil Novák tento aspekt románu výstižně charakterizuje již názvem své recenze (Žena navzdory dějinám i osudu):

\begin{abstract}
„Katalpě se podařilo vymodelovat postavu silnou, životaschopnou, autentickou; nepotřebuje ji psychologizovat ani detailně charakterizovat, stačí, že o ni vypravi. Čtenár tak nemusi zbytečně spekulovat o pohnutkách jejiho chováni, spiše jen bez dechu sleduje, jak se odviji linie lidského života v jistých podmínkách, v nichž hrdinka prokazuje velkou odhodlanost žit, naplnit své ženství, být užitečná. Jeji činy ji nezařazuji ani do kategorie hrdinek, ani do kategorie antihrdinek, je především ženou, která neni rozdrobena tíhou osudu, nepodléhá afektovaným emocím a s jistou odhodlaností se vyrovnává s tím, co postupně do jejîho života prichází, byt’ jsou to mnohdy fatálni události. "19
\end{abstract}

V samém závěru románu se ke slovu opět dostává mladá personální vypravěčka, která si klade nezodpověditelné otázky o ztrátách v př́ibuzenstvu - nejvíc podle ní ztratila babička, protože jí slábnoucí pamět nedovolila sečíst životní zisky. Obnova smyslového vnímání v co nejkonkrétnější podobě jednotlivých vjemů a nezapomenutelných obrazů je pro čtenáře největším ziskem, který román Jakuby Katalpy Němci přináší. Nahlédnutí do mentality a osudů širšího společenství nabízí autorka jen v menší míře.

Vyprávění dominuje strhující příběh jedné ženy, která prochází dvacátým stoletím ve střední Evropě s odolností, která tváří v tvář nepřetržité sérii ztrát a zklamání nepřestává udivovat. Tato postava se vymyká schematickému dělení na hrdiny a antihrdiny, dokonce není zcela jisté, zda je skutečnou ústřední postavou prózy. V atmosféře postupujícího chladu a lhostejnosti v ponuré a opouštěné krajině se spíše zdá, že hlavním hrdinou je samo odcházení.

Zajímavou interpretační možnost rozvíjí ve své recenzi románu Němci Marek Lollok, když vychází z původního významu slova Němec (= „němý člověk“ - z pohledu těch, kteří byli mocni slova, tj. Slovanů): „Nejsou lidé, o kterých se zde vypráví, zváni priléhavě „Němci“ spíse proto, že jsou vưči sobě němi, než pro svou - mnohdy stejně nejednoznačně určenou - národnost? Neplatí to alespoň o některých z nich? O nejdůležitějšich věcech svého života mluví leckteré postavy zřídka i se suými nejbližšimi, ostatně mladá žena, která se rozhodne bariéry založené na strojené zásadovosti prolomit a alespoň pro sebe si záludné otázky zodpovědět, musí vše činit bez podpory, uminěně a jaksi navzdory. I v tomto tématu, tedy narušeni mezilidských vztahů mezi

18 Tamtéž, s. 340-341.

19 NOVÁK, Radomil: Žena navzdory dějinám i osudu. Host, 2013, č. 1. Dostupné z: www.nakladatelství.hostbrno.cz/ohlasy/nemci/zena-navzdory-dejinam-i-osudu. 
blizkými, je Katalpa aktuálni, a obohacuje tak svůj text o nás a našich dlouholetých sousedech o dalši rovinu. " 20

Jana Semelková vyzdvihuje mj. členitost a barevnost mozaiky lidských osudů, kterou autorka ve svém románu vytváří: „Jakuba Katalpa vytvořila členitou mozaiku osudi̊ mnoha lidi, kteři se v určitých okamžicích svého života potkali na delši či kratši dobu. Všechny do jednoho ovlivnily „velké dějiny" - války pruni i druhá a pak poválečná doba. Prožijeme život jedné německé rodiny, která přijimala vše, co se děje kolem ni, a snažila se žít pokud možno nenápadně a bezkonfliktně, jejim cílem bylo hlavně přežit. Válka všem převrátila životni cestu. Autorka nám ukazuje, jak těžké je najit nový směr, někde opět zakořenit, vytvořit si znovu vlastni mistečko, navázat na zpřetrhané vazby a vztahy. [...] Malé střípky do sebe zapadaji jako puzzle a vytvářeji jeden velký, členitý a mnohabarevný obraz. Najednou přestaneme vidět černobile. “21

Jakuba Katalpa se románem Němci soustředěně vyhýbá sílícímu proudu v současné próze, ve kterém se vzklenutí epického oblouku považuje za nepoužitelnou rekvizitu dob dávno minulých. Katalpa je bytostnou, a tedy fabulující vypravěčkou, která věří v sílu imaginace a možnosti smyslového vnímání. Právě s pomocí všech smyslů se snaží zachytit nejen jednotlivé výjevy, ale i celé situace, jejichž symbolický význam se postupně vyjevuje.

Obnovování epického tvaru, který se zdál být již nenávratně rozpadlý, se v próze Němci neděje pouze postupy charakteristickými pro žánr románu. „Barevnost a členitost“, o níž se zmiňuje Jana Semelková, se týká pouze některých významových rovin textu - především volby událostí a postav, které postihují podstatné momenty doby a typických reáliî života sudetských Němců v pohraničí. Se samotnými postavami však autorka pracuje spíše s náznakovostí a záměrnou plošností příznačnou pro žánr novely.

Novelistickému žánru odpovídá také nepřehlédnutelná polemičnost v rovině axiologické - outsiderství, které jako rodové či kmenové prokletí pronásleduje hlavní postavu navzdory její odolnosti a aktivitě. Novelou byla do evropské prózy vnesena nehrdinská smrt postavy (zde v jistém smyslu až šokující sebevražda učitele skokem do studny). Permanentní oscilace mezi lyričností a epičností, která je žánru novely vlastní, je součástí stylotvorné strategie, která umožňuje sugestivně nastínit psychické zvláštnosti postav, zároveň je však i jistou polemikou s převažující hodnotovou orientací společnosti (v románu Němci jde o znejasnění tradičně ostrého rozlišování povahových rysů na osách dobro - zlo, aktivita - odevzdanost apod. $)^{22}$

Jakuba Katalpa nepolemizuje pouze s přístupy k tématům vysídlení, vykořenění a ztrát, které jsou v kontextu uměleckém i historiografickém zatíženy ideologickými stereotypy a přílišnou racionalitou při hledání jasných politických postojů, spravedlnosti atd. Polemizuje také s tendencí k opouštění bohatých tvárných možností, které v evropské próze vytvořily žánry románu a novely. Vědomí těchto možností zároveň předpokládá reflexi omezení fikčního světa, která z hledání vlastní pozice literatury vyplývají.

20 LOLLOK, Marek: Němci včera a dnes. In: iLiteratura.cz (2.12.2012). Dostupné z: iLiteratura.cz/Clanek/30909/katalpa-jakuba-nemci.

21 SEMELKOVÁ, Jana: Geografie ztráty - román Němci Jakuby Katalpy. In: Kultura 21.cz (2.4.2013). Dostupné z: www. Kultura21.cz/literatura/6302-nemci-jakuba-katalpa.

22 Blíže k poetologickým charakteristikám novelistického žánru v širším evropském pohledu srov. SCHLAFFER, Hannelore: Poetik der Novelle. Stuttgart - Weimar: Metzler, 1993. 
V moderní a zejména postmoderní próze jde o více či méně radikální (a neodstranitelnou) mezerovitost fikčního světa, k níž se svou tvorbou hlásí i Jakuba Katalpa. Akcentováním herního principu literární komunikace si autorka připravila cestu k alternativním způsobům rozvíjení významu fenoménů odcházení, vykořenění a ztráty. Tragičnost válečných a těsně poválečných událostí přirozeně zdůrazňuje roli přímých aktérů, a tak odsouvá další generace do stále pasivnějších rolí. Jakuba Katalpa se omračujícímu tlaku „velké“ historie pokusila vzepřít vytvořením literárního textu, který pozapomenuté umění vyprávět znovu spojuje s kladením závažných otázek o nedávné minulosti a traumatech s ní spojených.

\section{Literatura}

BALDICK, Chris: The Oxford Dictionary of Literary Terms. 4. vyd. Oxford: Oxford University Press, 2015. $392 \mathrm{~s}$.

BUCHANAN, Ian: A Dictionary of Critical Theory. 1. vyd. Oxford: Oxford University Press, 2010. 500 s.

COHNOVÁ, Dorrit: Signály fikčnosti: Naratologický pohled. Přel. M. Orálek. In: Aluze 10, 2008, č. 1, s. 40-54.

DENEMARKOVÁ, Radka: Penize od Hitlera. Brno: Host, 2006. 248 s.

DOLEŽEL, Lubomír: Inovace jako transformace fikčniho světa. In: Týž: Studie z české literatury a poetiky. Ed. a překl. B. Fořt. Praha: Torst, 2008, s. 289-300.

DOLEŽEL, Lubomír: Fikčni a historický narativ. In: Týž: Studie z české literatury a poetiky. Ed. a překl. B. Fořt. Praha: Torst, 2008, s. 301-336.

DVOřÁK, Tomáš - KOVAŘÍK, David - von ARBURG, Adrian: Německy mluvici obyvatelstvo v Československu po roce 1945. Brno: Matice moravská, 2010. $576 \mathrm{~s}$.

FOǨT, Bohumil: Úvod do sémantiky fikčnich světů. Brno: Host, 2005. 148 s.

HAHNOVÁ, Eva: Sudetonèmecké vzpomínáni a zapomínáni. Praha: Votobia, 2002. $234 \mathrm{~s}$.

HILLEBRAND, Bruno: Theorie des Romans: Erzählstrategien der Neuzeit. Frankfurt am Main: Fischer, 1996. $540 \mathrm{~s}$.

JANOUŠEK, Pavel: 969 slov o próze - Jakuba Katalpa: Němci. Host, Brno 2012. In: Tvar 21, 2012 , s. 3.

KATALPA, Jakuba: Němci. 1. vyd. Brno: Host, 2012. 424 s.

KURAL, Václav: Misto společenství - konflikt! Praha: Ústav mezinárodních vztahů, 1994. 295 s.

LOLLOK, Marek: Němci včera a dnes. In: iLiteratura.cz (2.12.2012). Dostupné z: www.iliteratura. cz/Clanek/30909/katalpa-jakuba-nemci.

MARTÍNEZ, Matías (ed.): Handbuch Erzählliteratur: Theorie, Analyse, Geschichte. Stuttgart: Metzler, 2011. $308 \mathrm{~s}$.

MOCNÁ, Dagmar - PETERKA, Josef a kol.: Encyklopedie literárních žánrư. Praha - Litomyšl: Paseka, 2004. $704 \mathrm{~s}$.

KNAPPOVÁ, Miloslava: Jak se bude vaše dítě jmenovat? 5. vyd. Praha: Academia, 2010. 784 s.

MOLDANOVÁ, Dobrava: Naše př́imení. 4. vyd. Praha: Agentura Pankrác, 2015. 232 s.

MYŠKOVÁ, Ivana: Román Němci může být pro čtenáře velkým překvapením (31.1.2013 - rozhlasový rozhovor s Jakubou Katalpou). Dostupné z: http: vltava.rozhlas.cz/roman-nemci-muze-byt-pro-ctenare-velkym-prekvapenim. 
NOVÁK, Radomil: Žena navzdory dějinám i osudu. In: Host, 2013, č. 1. Dostupné z: www.nakladatelství.hostbrno.cz/ohlasy/nemci/zena-navzdory-dejinam-i-osudu.

POSPÍŠIL, Ivo: Genologie a proměny literatury. Brno: Masarykova univerzita, 1998. $154 \mathrm{~s}$.

POSPÍŠIL, Ivo: Transcendence literatury a historicita románu: kořeny a druhá polovina 20. století. In: Týž: Ruský román znovu navštívený. Brno: Universitas, 2005, s. 99-111.

SEMELKOVÁ, Jana: Geografie ztráty - román Němci Jakuby Katalpy. In: Kultura 21.cz (2.4.2013).

Dostupné z: www.Kultura21.cz/literatura/6302-nemci-jakuba-katalpa.

SCHLAFFER, Hannelore: Poetik der Novelle. Stuttgart - Weimar: Metzler, 1993. 323 s.

STANĚK, Tomáš: Odsun Němcơ z Československa 1945-1947. Praha: Academia, 1991. 536 s.

STANĚK, Tomáš: Poválečné „excesy “v českých zemich v roce 1945 a jejich vyšetřování. Praha: Ústav pro soudobé dějiny AV ČR, 2005. 366 s.

STANĚK, Tomáš - von ARBURG, Adrian (eds.): Vysídlení Němců a proměny českého pohranič 19451951 I. Středokluky: SUSA, 2010. $376 \mathrm{s.}$

SVATOŇ, Vladimír: K epičnosti románu a problému románu historického. In: Litteraria humanitas:

Genologické studie I. Eds. M. Mikulášek - D. Kšicová. Brno: Masarykova univerzita - Filozofická fakulta, 1990, s. 248-261.

TUČKOVÁ, Kateřina: Vyhnáni Gerty Schnirch. Brno: Host, 2009. 413 s.

Doc. Dr. Petr Kučera, Ph.D.

Katedra germanistiky a slavistiky

Filozofická fakulta, Západočeská univerzita

Riegrova 11, 30614 Plzeň, Česká republika

pekucera@kgs.zcu.cz 
